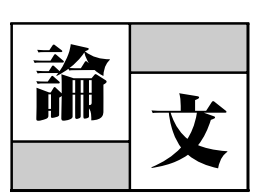

\title{
樹脂ペレット飢餓供給時における連続可塑化過程の可視化解析
}

\author{
高 次 聡*1 横 井 秀 俊*2
}

\section{Visualization Analysis on Continuous Plastication Process of Resin Pellets under Starve Feeding Condition}

\begin{abstract}
Takatsugi, Satoshi*1/Yokoi, Hidetoshi*2
To investigate the influence of the pellet starve feeding condition on the continuous plastication process with PP (hot cut pellet), in this study, visualization analysis was performed and plastication mechanism under the pellet starve feeding condition was revealed. It was confirmed that both the pellet gathering point and the melting start point under the starve feeding process relatively moved to the downstream region along the screw compared to one under the pellet flood feeding, and also this phenomenon was encouraged by increase in the starvation ratio and the screw rotation rate. Also confirmed that although the melting completion point in a low screw rotation rate was located almost at same point as one under the flood feeding, the melting did not complete in a high screw rotation rate accompanied with generation of solid bed break-up.

According to the results, the following plastication process under the starve feeding condition was suggested. The resin pellets are transported with a low filling density through the upstream region of the feed zone, to aggregate in the downstream region while they are heat-receiving and rolling. When the pellets those surfaces are heated at the compression zone have been integrated by aggregation, they enclose a high temperature interface between each of them. Hence the melting completes in a short period of time without any obvious generation of the melt pool (MP). Although the pellets are molten efficiently in a low screw rotation rate under the starve feeding condition, increase in the screw rotation rate results in a delay in the plastication process, and it can lead to poor melt failure and generation of the solid bed (SB) break-up (BUP).
\end{abstract}

Key words : visualization cylinder, plastication process, starve feeding, extended image

\section{1. 緒言}

射出成形機において，加熱シリンダ内への樹脂ペレット の噛込み状況およびその後の可塑化スクリュによる樹脂ぺ レットの輸送状況は, 可塑化・計量過程に大きな影響を与 え，成形品の品質を左右する。精密な成形を行うためには, それらの安定化が重要な課題である，著者らはホッパー下 部における樹脂ペレットの噛込み状況の影響を調査するた め, シリンダ内とホッパー下部噛込み領域を直接観察でき る可視化加熱シリンダ ${ }^{1)}$ 用いて，7種類の樹脂ペレット の噛迀み挙動とスクリュ表面温度, ペレットの固体摩擦係

\footnotetext{
*11ファナック(株ロボマシン事業本部

Robomachine Business Div., FANUC Corporation 山梨県南都留郡忍野村 ( ₹401-0597)

Oshino-mura, Minamitsuru-gun, Yamanashi, 401-0597, Japan takatsugi@fuji.email.ne.jp

*2 東京大学生産技術研究所

Institute of Industrial Science, The University of Tokyo 東京都目黒区駒場 4-6-1（广153-8505）

4-6-1, Komaba, Meguro-ku, Tokyo, 153-8505, Japan 2016.8.8 受理
}

数との相関解析を行い, 特定の PBTにおける噛込み不良 現象の生成機構を明らかにした ${ }^{2)}$ 。これまで，射出成形機 に樹脂ペレットを飢餓供給することで，噛込み不良が改善 する事例があることは経験的に知られていた。飢餓供給は， 通常の満杯供給に対して, 可塑化スクリュ本来の固体輸送 能力を下回るように樹脂ペレット量を制限し，ホッパーロ から供給する方法である．飢餓供給は一般的に可塑化能力 低減という短所を持つものの, 樹脂ペレットの噛込み性向 上，脱気性向上に効果があることが商業的に謳われ，現象 の解明がなされていない中で, 経験的には有効性が知られ ている。しかしながら，押出機における添加剤の混練性改 善 ${ }^{3}$, 射出成形機における脱気性向上 ${ }^{4}$ などの対策手段とし て紹介された報告はなされているものの，飢餓供給時の樹 脂可塑化プロセスについては，これまで明らかにされてい なかった。

そこで本研究では，既報 ${ }^{1)} の$ 可視化加熱シリンダを用い て飢餓供給時の可塑化状況を観察し, 同時にシリンダ内の 樹脂圧力, 樹脂温度を測定することで, 飢餓供給時の可塑 化メカニズムを詳細に調査することを目的とした. 


\section{2. 実験方法}

\section{1 飢餓供給の方法}

固体樹脂の噛込み不良現象が発生した場合の有効な対応 策として，ホッパーロへのペレット定量供給装置を用いて， 飢餓供給を行うことが知られている。ここでは，飢餓供給 の度合い (以下, 飢餓率) を変化させて, 飢餓供給時のホッ パー下部およびシリンダ内における樹脂挙動を調査する. ここで, 飢餓率は, 次式で与えられる ${ }^{5}$.

$$
S=\left(1-G_{S} / G_{0}\right) \times 100
$$

\section{$S$ : 飢餓率 $(\%)$ \\ $G_{s}$ : 飢餓供給時の樹脂質量流速 \\ $G_{0}:$ 満杯供給時の樹脂質量流速}

ここで， $G_{s}, G_{0}$ はともに同一のスクリュ回転速度にお けるスクリュ軸方向の質量流速である。また満杯供給とは, 定量供給装置からの樹脂送り出し量がノズルからの可塑化 吐出量に等しいか，それ以上となる供給状態のことを指し， 以下では，満杯供給状態を飢餓率 $0 \%$ として表記する。

(1)式は成形機のスクリュ回転速度を用いて書き換えると 以下のように近似できる5 .

$$
S=\left(1-N_{0} / N_{S}\right) \times 100
$$

$N_{0}$ : 満杯供給時のスクリュ回転速度

$N_{S}$ : 飢餓供給時のスクリュ回転速度

ここでは， $N_{0}, N_{s}$ のいずれも定量供給装置からの送り 出し量は同一とする. 定量供給装置の送り出し量を調節し て飢餓率を変化させる場合には，(2)式から，

$$
N_{0}=(1-S / 100) N_{S}
$$

であるから，スクリュ回転速度が $N_{0}$ のときに満杯供給と なるような定量供給装置の送り出し量に設定すれば, 回転 速度が $N_{S}$ のときに飢餓率が $S$ となる.
本研究では，定量供給装置と成形機のホッパー口の間を 透明な供給パイプで連結し，スクリュ位置を固定させて回 転させる連続可塑化中に，樹脂レベルが一定になるような 定量供給装置の送り出し量を求めた。このときを飢餓率 $0 \%$ とする. 飢餓率 $0 \%$ 時には供給パイプ内の樹脂レベ ルを一定に保つようにした．これは，ホッパーロにおける ペレット自重による加圧効果を考慮したためで，実際に ホッパーをつけて可塑化を行う場合とほぼ等価であると考 えられる。

本研究では，飢餓率をさまざまに変化させてポリプロピ レンのホットカット・ペレット(直径 $3 \mathrm{~mm} \times$ 長さ $3 \mathrm{~mm}$; 以下 PPH 3）を供給し，ホッパー下部（成形機正面側，背 面側）およびシリンダ内（供給部，圧縮部，計量部）を可 視化観察した。同時に，シリンダとノズルにおける樹脂圧 力と樹脂温度を計測して可塑化状況の評価を行った。

\section{2 実験装置}

本研究に使用した可視化加熱シリンダの概略を図 1 に示 す。ホッパー下部は，ホッパー口部分を形状加工した石英 ガラス製ブロックを直接組込み, ホッパー下部におけるシ リンダ内への樹脂ペレット噛込み状況を詳細に解析できる 構造となっている ${ }^{1)}$. 観察空部は成形機の正面側と背面側 の 2 箇所とし，スクリュのフライト開始端から約 3 ピッチ の範囲内のペレット挙動を, 両側から同時観察可能となっ ている.

可視化加熱シリンダを搭載した射出成形機は, 型締力 $300 \mathrm{kN}$ の AUTOSHOT C-30 A (ファナック株) とした. ガラスブロック内部のペレット挙動は高速ビデオカメラ (HSV-400, (株ナック)にて撮影し, 画像処理システム (ID -8000, (株ナック) を用いて, 成形機正面と背面側の観察 画像をワイプユニットを用いて同一フレーム内に合成・記 録した。定量フィーダ (ACCURATE DRY MATERIAL FEEDER，(株)クマエンジニアリング）を用いて PPH 3 を 飢餓供給し, 樹脂圧力と樹脂温度の計測・記録には, 樹脂

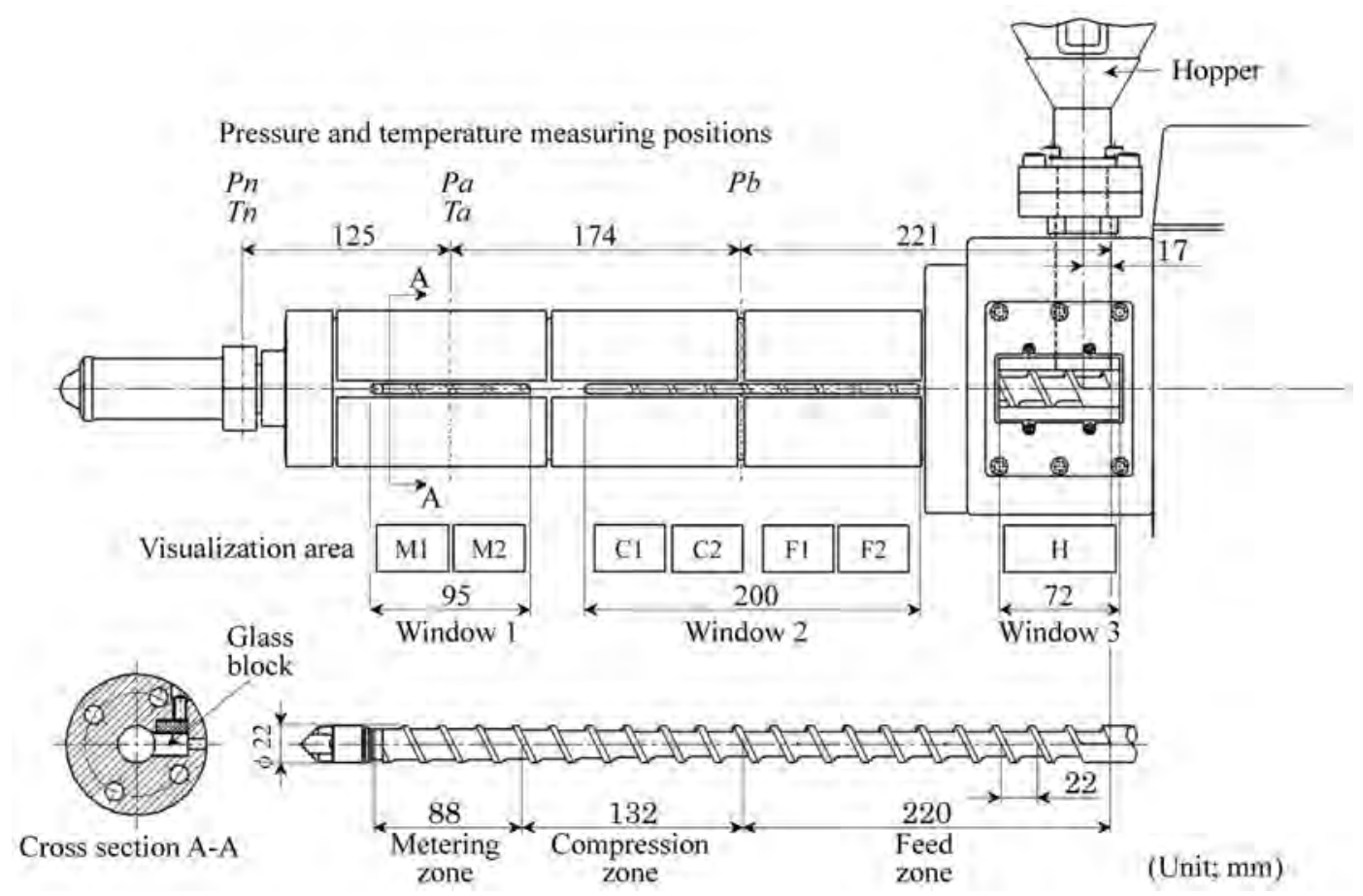

Fig. 1 Visualization heating cylinder and feed throat 


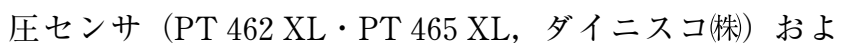
び赤外放射温度計 $\left(150^{\circ} \mathrm{C} \sim 380^{\circ} \mathrm{C}\right.$ 用, (株ニレコ), 計測シ ステム（MOBAC 220，(株ニレコ）を使用した. 計測位置 はノズル部, 計量部, 圧縮部入口の 3 箇所（樹脂温度は 2 箇所）とし, それぞれの計測樹脂圧力を $P n, P a, P b$, 樹脂 温度を $T n, T a$ と表記した。

\section{3 実験条件}

本研究では, PPH 3 (ハイポール J 700, 三井石油化学 工業(株)/現プライムポリマー(侏), MFR $=11 \mathrm{~g} / 10 \mathrm{~min}, \mathrm{Tm}$ $=165^{\circ} \mathrm{C}$ ）を用い, 設定温度はノズルからホッパー下部ま で順に200/210/200/190/190/40（ ${ }^{\circ} \mathrm{C} ）$ とした. スクリュ を最前進位置に固定しスクリュ回転のみを行う連続可塑化

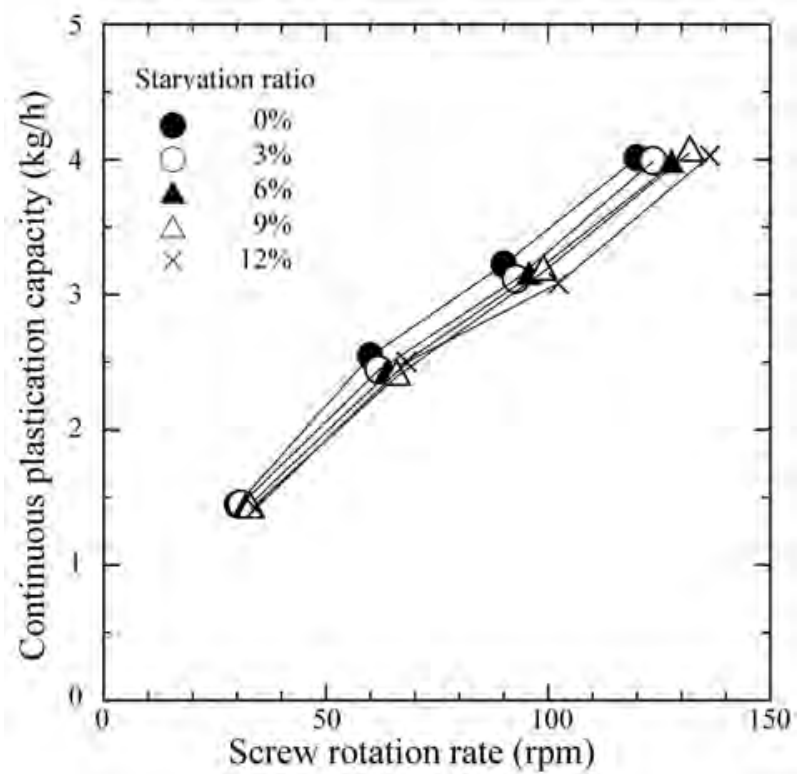

Fig. 2 Relation between continuous plastication capacity and starvation ratio

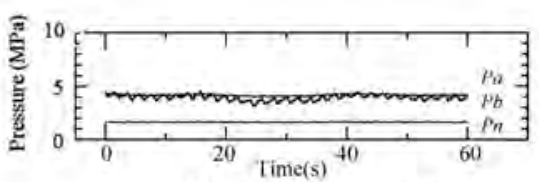

(1) Starvation ratio $0 \%$

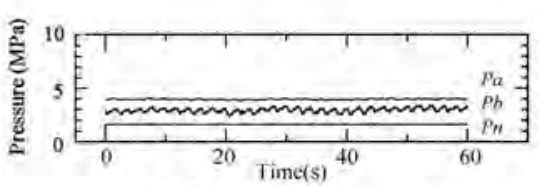

(2) Starvation ratio $6 \%$

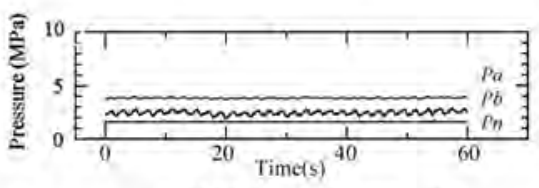

(3) Starvation ratio $12 \%$

(a) Screw rotation rate $30 \mathrm{rpm}$

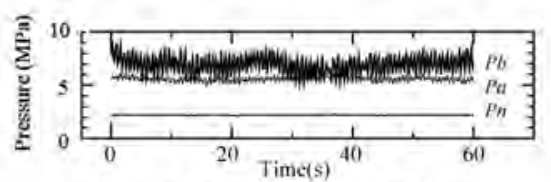

(1) Starvation ratio $0 \%$

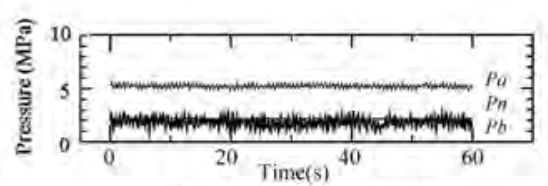

(2) Starvation ratio $6 \%$

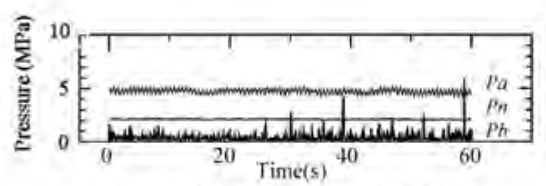

(3) Starvation ratio $12 \%$

(b) Screw rotation rate $90 \mathrm{rpm}$

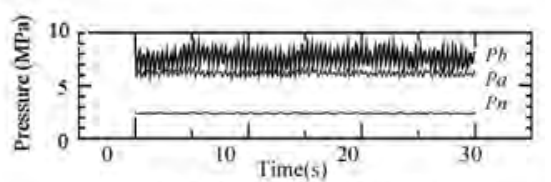

(1) Starvation ratio $0 \%$

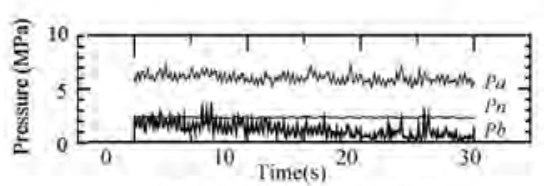

(2) Starvation ratio $6 \%$

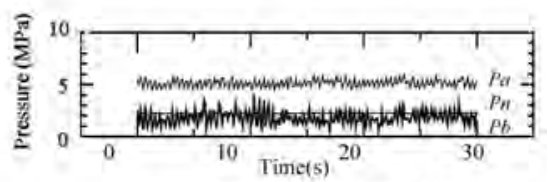

(3) Starvation ratio $12 \%$

$P n$ : Pressure at nozzle $P a$ : Pressure at metering zone $\mathrm{Pb}$ : Pressure at compression zone

(c) Screw rotation rate $150 \mathrm{rpm}$

Fig. 3 Resin pressure at each measuring point (Screw rotation rate $30,90,150 \mathrm{rpm} /$ Starvation ratio $0,6,12 \%$ ) 


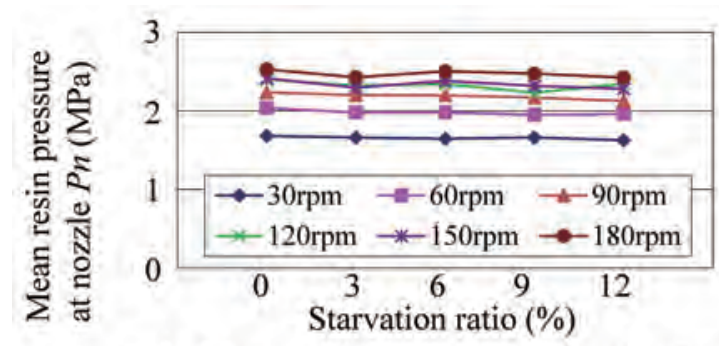

(1) Mean resin pressure at nozzle $P n$

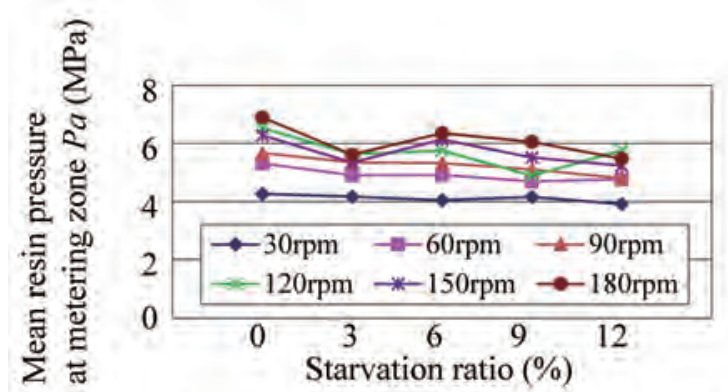

(2) Mean resin pressure at metering zone $\mathrm{Pa}$

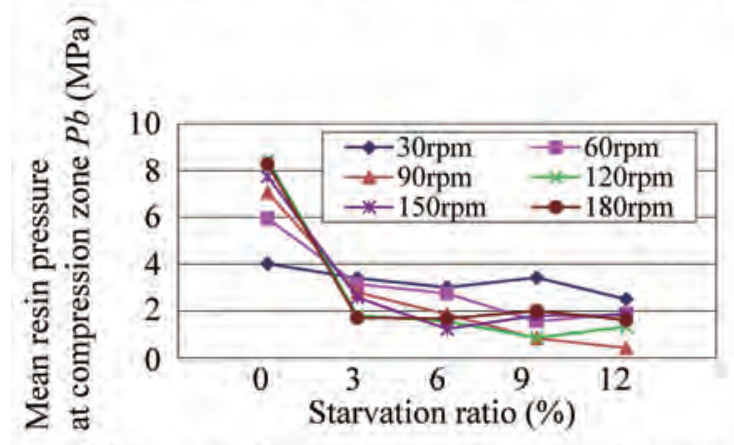

(3) Mean resin pressure at compression zone $\mathrm{Pb}$

Fig. 4 Mean resin pressure as a function of starvation ratio

(Screw rotation rate $30,60,90,120,150,180$ rpm)

動幅（最大・最小の圧力差）は $P n$ が最も小さく $, P a, P b$ の順に大きくなった。圧縮部では未溶融ペレット群である ソリッドベッド（以下，SB）が流入し，シリンダ内壁面・ スクリュ底面と干渉することを反映して,$P b$ の変動幅が 増大するものと理解される. スクリュ回転速度の増加にと もなって SB の流入量も増加するため, 変動幅も大きく なっている. $P b$ では, 飢餓率 $0 \%$ の $90 \mathrm{rpm}, 150 \mathrm{rpm}$ で，SB のブレークアップ (以下，BUP) 現象(6), を示す特 徵的な波形(緩やかな圧力変動) が観察され, 特に $150 \mathrm{rpm}$ では，飢諓率 $6 \%, 12 \%$ の $\mathrm{Pb}$ にも BUP 現象の生成を同 様に確認することができる.

図 4 から，ノズル部圧力 $P n$ の平均值は，同一スクリュ 回転速度では, 満杯供給/飢餓供給を問わず飢餓率ととも に微減するが，その值に大きな差は見られない。また，同 一飢餓率では，回転速度にともない概ね増加傾向を示した。 計量部圧力 $P a$ は, $90 \mathrm{rpm}$ 以下では $P n$ と同様の傾向を示 す. $120 \mathrm{rpm}$ 以上では，いずれの回転速度でも満杯供給時 に最大となり, 飢餓率 $3 \%$ を除いて, 飢餓率とともに漸 減傾向を示している. 圧縮部圧力 $P b$ は, いずれの回転速
度でも満杯供給時に最大值を示すが，Pa と相違して $3 \%$ の飢餓供給から急減し, 以後, 飢餓率の増加とともに緩や かに減少して推移する。これは, $P b$ の計測位置が圧縮部 入口にあり，後述するように，計測位置に扔ける溶融樹脂 の充満率が飢挠供給によって低くなることを反映したもの と理解される。なお， $150 \mathrm{rpm}$ および $180 \mathrm{rpm} の P b$ は, 後述の図 11(2)で示されるように, 計測位置が溶融開始点 よりも上流側にあったため, 溶融樹脂圧力の計測に対応し ていないことに注意を要する.

\section{3 樹脂温度測定結果}

図 5 に, 可塑化実験における樹脂温度変動 $(150 \mathrm{rpm})$ の計測結果を例示する．また，各条件での 30 秒間の樹脂 温度変動の相加平均を図 6 に示す。

可塑化中のノズル部, 計量部の樹脂温度 $T n, T a$ は, い ずれのスクリュ回転速度においてもほとんど飢餓率の影響 を受けず, $T n$ では $0 \sim 1{ }^{\circ} \mathrm{C}, T a$ では $2 \sim 2.5^{\circ} \mathrm{C}$ 程度の変動 範囲内に収まっていることが確認された。平均樹脂温度の 変化を示す図 6 では，ノズル部の樹脂温度 $T n$ はいずれの 飢諓率でもスクリュ回転速度増とともに上昇すること, 計 量部の $T a$ は，いずれのスクリュ回転速度でも飢餓率によ らず $0.5^{\circ} \mathrm{C}$ 以内の範囲に分布するが, 飢餓率の増加にとも なって各スクリュ回転速度間の変動幅が縮小することが示 された。

\section{4. 可視化観察実験}

\section{1 ホッパー下部の可視化観察結果}

ホッパー下部の噛込み状況を成形機正面側と背面側の両 面から同時に観察した結果, 以下のような状況が示された. 図 7 (1) に示す $90 \mathrm{rpm}$ の満杯供給では, ホッパーロから供 給された樹脂ペレットは, 背面側 1 ピッチ目への落下を開 始する (同図 A)，次に正面側 1 ピッチ目への落下が始ま り(同図 A')，直ちにスクリュ回転方向に移動を開始す る.2 ピッチ目（同図 B およびB”）でほぼスクリュ溝内一 周を隙間なく充満するが，ペレット間に空隙が存在するた め，各ペレットは運動の自由度を有する. 3 ピッチ目（同 図 C および C’）では空隙が消失し，各ペレットが拘束し 合った塊となり，剛体のような滑り挙動を開始する。この ペレット塊は，スクリュ回転方向速度成分と，スクリュ中 心軸方向速度成分を持つ様子が観察された。

次に飢餓供給時の観察画像（90 rpm，飢餓率 $6 \%$ ）を 図 7 (2) に示す。飢餓供給時に, ペレットはホッパーロか ら断続的に落下する，正面側ではペレットが充満するには 至らず(同図 A)，未充填領域が広がる。背面側でもペレッ トはスクリュ下方に落下するが (同図 $\left.\mathrm{A}^{\prime}\right)^{\prime}$ )，スクリュ回 転にともない押し側フライトに沿うようにペレットが堆積 する様子が観察された(同図 B').ペレットは背面側に偏っ た形で堆積し，スクリュ回転方向速度成分を持たないまま 下流側へ移送される特徵的な様子が観察された。

比較のため, 図 7 (3)に $30 \mathrm{rpm}$, 飢餓率 $6 \%$ 時の観察 画像を示す.1〜2 ピッチ目でペレットはスクリュ溝内を充 満せず， 3 ピッチ目（同図 C および C’）で概ね充満する ように見える. しかしながら, 後述のシリンダ内可視化観 察結果から明確になるように，この時点では各ペレット間 にまだ空隙が存在し，充満完了していない. 


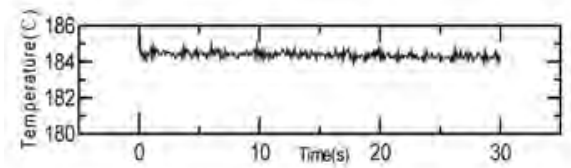

(1) Starvation ratio $0 \%$

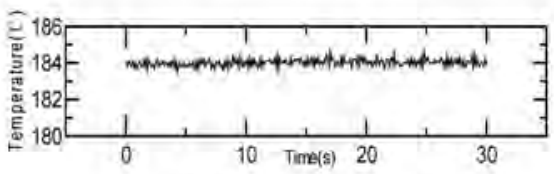

(2) Starvation ratio $6 \%$

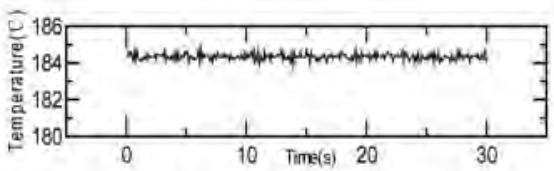

(3) Starvation ratio $12 \%$

(a) Resin temperature at nozzle $T n$

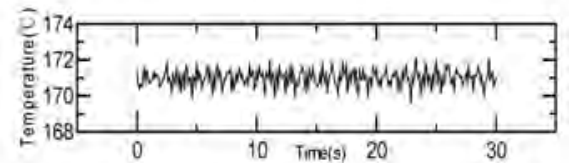

(1) Starvation ratio $0 \%$

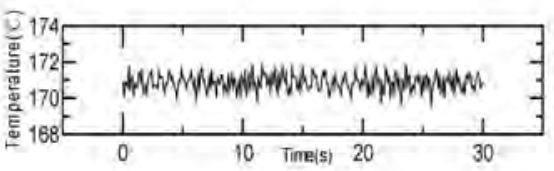

(2) Starvation ratio $6 \%$

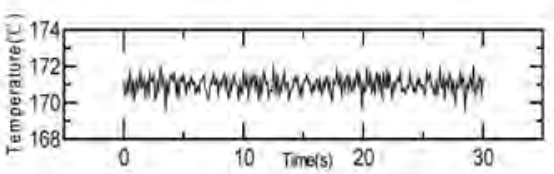

(3) Starvation ratio $12 \%$

(b) Resin temperature at metering zone $\mathrm{Ta}$

Fig. 5 Resin temperature at each measuring point

(Screw rotation rate $150 \mathrm{rpm} / \mathrm{Starvation}$ ratio $0,6,12 \%$ )

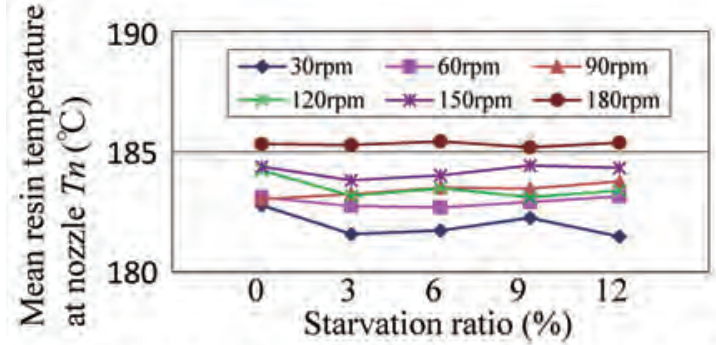

(1) Mean resin temperature at nozzle $T n$

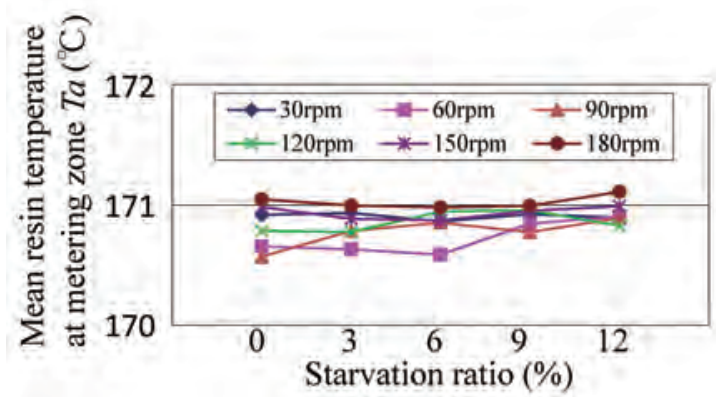

(2) Mean resin temperature at metering zone $\mathrm{Ta}$

Fig. 6 Mean resin temperature as a function of starvation ratio

(Screw rotation rate $30,60,90,120,150,180$ rpm)

以上のように，ホッパー下部における可視化観察の結果， 飢餓率が低い場合には，スクリュ溝内を埋める樹脂ペレッ 卜間に多少の空隙が空いている程度であるが，飢餓率が高 い場合には，ホッパーロから供給された樹脂ペレットはま ず，スクリュの成形機背面側に充填され, その量が徐々に 増加する.やがてスクリュ溝の上側からスクリュ表面に引 きずられて成形機正面側に回り込み，溝内を完全に充満す
ることが明らかになった，完全充満までは，正面側からの 観察では，ペレットはほとんど見えず，スクリュ下部に少 量見えるペレットをスクリュのフライトが下流方向に掻き 取っていく様子が見受けられる，このとき，ペレットはス クリュ回転方向速度成分をほとんど持っておらず，溝内を 完全充満したのちスクリュ回転方向速度成分を持つように なる.この完全充満位置を Fu とすると, ホッパーロから $\mathrm{Fu}$ までの距離は, 同一スクリュ回転速度ならば飢餓率の 増加とともに増加し, 同一飢餓率ならばスクリュ回転速度 の増加にともない微増する傾向が示された。

\section{2 シリンダ内の可視化観察結果}

シリンダ内の可視化観察から，飢餓供給時のホッパー下 部の観察（図 7 (3) 参照）ではペレットが完全充填されて いると思われていたものの，実際にはまだ少し隙間を有し ており, 個々のペレットには回転等, 多少の運動の余地が 残されていることが確認された. 図 1 に示す供給部 F 2 ( ス クリュ 6〜 7ピッチ目) で，個々のペレットは運動の自由 度を失い，相互に拘束し合ったペレット塊となる。このと きには, 各ペレット表面と加熱シリンダ内壁面の接触領域 ですでに溶融が始まりかけているものと思われ，やがてぺ レット表面の溶融樹脂がペレット塊へと含浸し, ペレット 間の隙間からスクリュ表面が見えなくなる.ペレット間か らスクリュ表面が見えなくなる位置を Ms とすると, ホッ パー口から Ms までの距離は, 同一スクリュ回転速度では 飢餓率の増加にともない長くなる。 また, 同一飢餓率で は, $90 \mathrm{rpm}$ 以下でスクリュ回転速度の増加にともない微 増する傾向が見られた.

満杯供給条件下での従来の可視化観察でも，スクリュ回 転速度の増加にともない, 樹脂の溶融開始位置はノズル側 に移行することが確認されている．しかしながら，飢餓率 を増加させた場合には, スクリュ溝内でのペレット充填率 


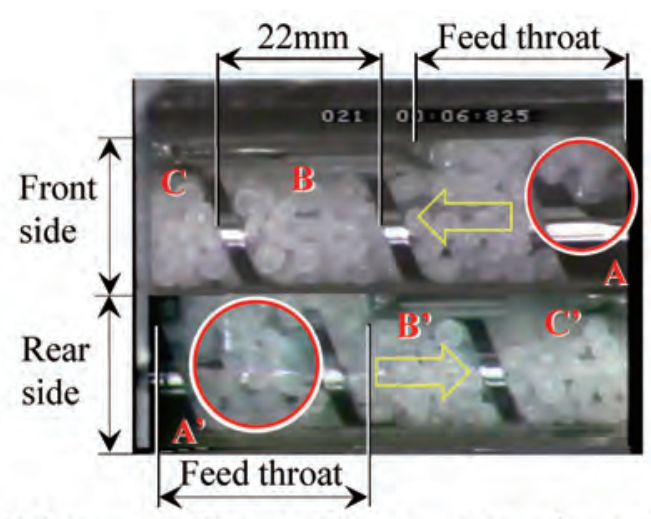

(1) Screw rotation rate $90 \mathrm{rpm}$, starvation ratio $0 \%$

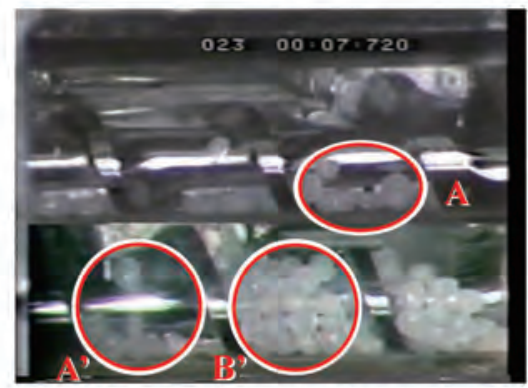

(2) Screw rotation rate $90 \mathrm{rpm}$, starvation ratio $6 \%$

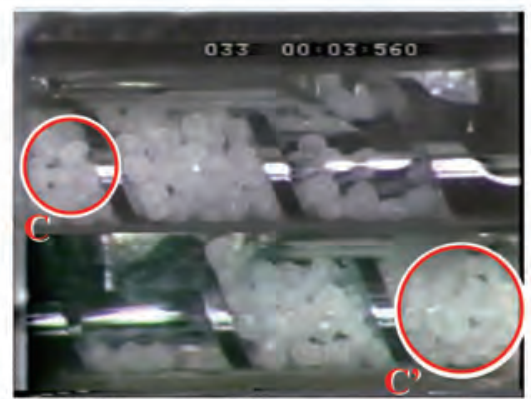

(3) Screw rotation rate $30 \mathrm{rpm}$, starvation ratio $6 \%$

Fig. 7 Comparison of the visualization images of feed throat under various material-feeding conditions

が供給部で低く保たれる結果，樹脂の押付け圧力の低下に よる伝熱効果の低下をもたらすこととなる。また,スクリュ 中心軸方向への送り速度が速くなるため, シリンダ内での 滞留時間も短くなることが想像される。これらより，樹脂 の溶融開始位置は, 飢餓率増加により一層ノズル側へとシ フトすることが示唆された.

\section{3 積層擬似展開画像}

シリンダ内の可視化観察結果から得られた積層擬似展開 画像8のうち，スクリュ回転速度 30，90，150 rpm につい て，それぞれ図 8 , 図 9 , 図 10 に示す. 飢餓率 $0 \%$ の画 像を比較すると，スクリュ回転速度 $30 \mathrm{rpm}$ では Tadmor 型の，それ以外の回転速度では Lindt 型の溶融状態を呈し ている. 図 8(2) から, $30 \mathrm{rpm}$ の飢餓率 6\% では, ペレッ トが充満する位置 Fu が供給部 F 2 に観察される. 一方, 図 8(3) から, 飢餓率 $12 \%$ では供給部 F 2 にはペレットが 存在せず，ペレットが充満する位置 Fu は供給部 F 1 にシ フトする.このことから, ペレットのスクリュ溝内充填完 了位置 $\mathrm{Fu}$ は, 飢餓率の増加に伴い, 供給部 $\mathrm{F} 2$ から $\mathrm{F} 1$

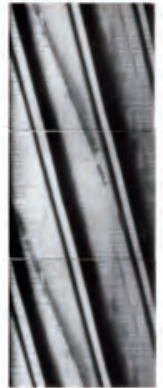

C1

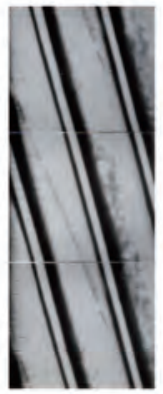

$\mathrm{C} 1$

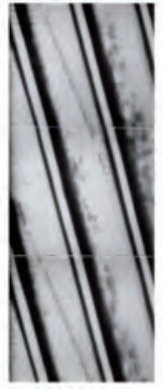

$\mathrm{C} 1$

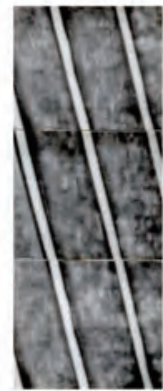

F1

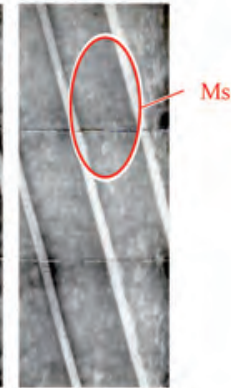

F2
(1) Starvation ratio $0 \%$

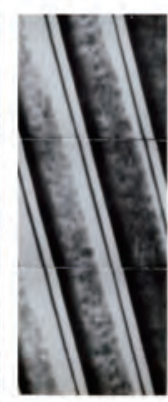

$\mathrm{C} 2$

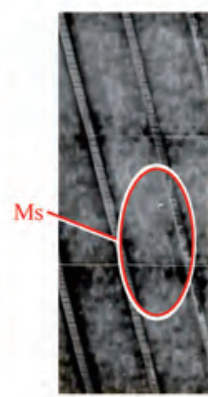

F1

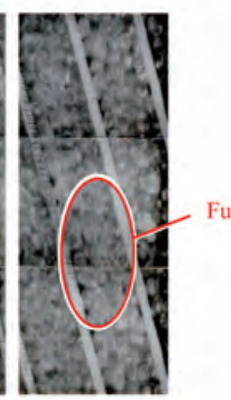

F2
(2) Starvation ratio $6 \%$

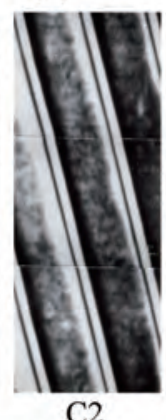

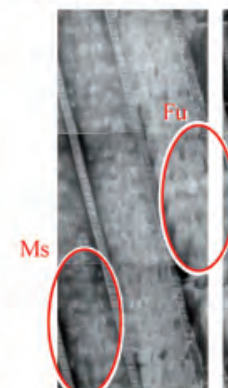

F1

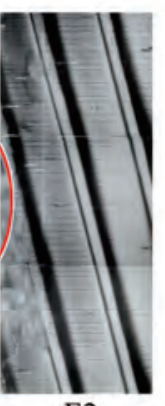

F2
(3) Starvation ratio $12 \%$

Fig. 8 Extended image of screw channel (30 $\mathrm{rpm} /$ Starvation ratio $0 \%, 6 \%, 12 \%$ )

へと次第に移動することが分かる，しかしながら，溶融が 進み Ms，拈よび SBがほぼ消失する位置 Mf は，いずれ の飢挠率でもそれぞれ供給部 F 1 と計量部 M 1 である.

図 9 に示す $90 \mathrm{rpm}$ では，全般に供給部におけるペレッ 卜の充満が高まる傾向が示される，飢餓率 $6 \%$ では, 供 給部 F 2 の上流側（図中右側）でも未充填現象はほとんど 確認されない. $12 \%$ では， $30 \mathrm{rpm}$ でほぼ空洞であった供 給部 F 2 も概ねペレットが充満している. ペレット充填完 了位置 $\mathrm{Fu}$ は， $30 \mathrm{rpm}$ 同様に飢餓率の増加にともない F 2 から F 1へと次第に移動する．メルトプール（以下，MP) が発生し SB が薄く透け始める位置は供給部 F 1 である. また，同一飢餓率においては，スクリュ回転速度の増加に ともないやや下流側へシフトする傾向が見られるが，飢餓 率ほどには影響を与えない. SBがほぼ消失する位置 Mf は飢餓供給時に満杯供給時よりも下流側（図中左側）にシ フトするものの， Ms と Mf 間の距離は飢餓供給時の方が 短く, 短時間の内に溶融が完了することが明らかになった.

図 10 に示すスクリュ回転速度 $150 \mathrm{rpm}$ では, 飢餓供給 時にBUP の発生が確認された．満杯供給時には圧縮部 C 


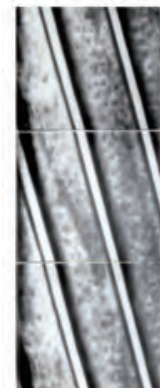

C1 C2

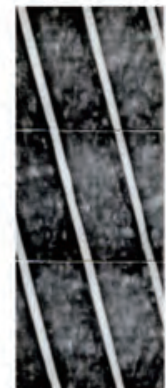

F1

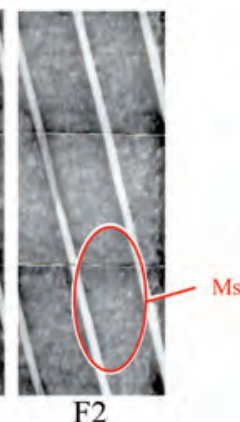

F2
(1) Starvation ratio $0 \%$

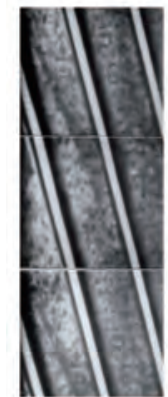

$\mathrm{C} 1$

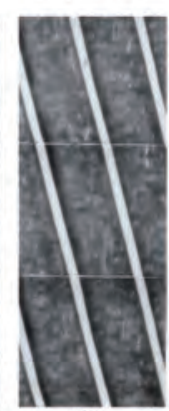

$\mathrm{C} 2$

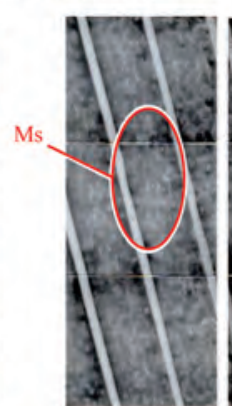

F1

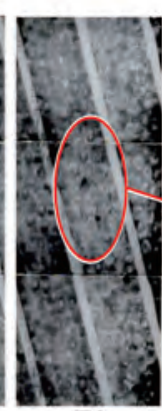

F2
(2) Starvation ratio $6 \%$

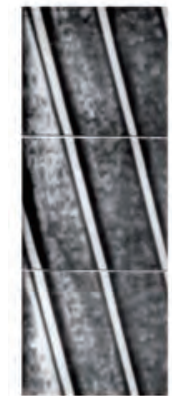

$\mathrm{C} 1$

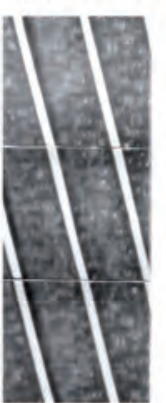

$\mathrm{C} 2$

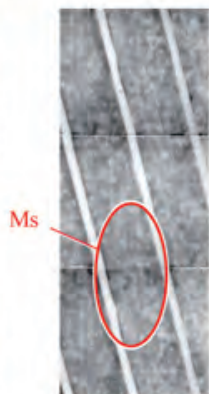

F1

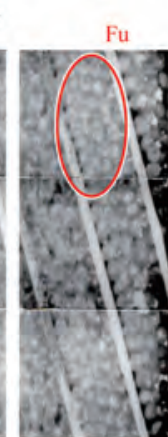

F2
(3) Starvation ratio $12 \%$

Fig. 9 Extended image of screw channel $(90 \mathrm{rpm} /$ Starvation ratio $0 \%, 6 \%, 12 \%)$

2 から C 1 にわたる範囲で SB が薄く透け始めるが，飢餓 供給時には C 2 でまだペレットの輪郭が確認され，C1に 到達したペレットはBUPを引き起こす。このBUPは, 回転速度と飢餓率にかかわらずほぼ一定の位置で発生した。 満杯供給で BUP が発生していない場合には，M 2 におい て僅かに SB が確認されるが，M 1 においてはほほ MP と なり溶融が完了した。飢餓率 $6 \%$ では，C1においても 各ペレットの境界が明瞭に確認される。また, SB 内部で は, 明るい所と暗い所が出現し, 局所的に溶融が進んだ領 域が形成されつつある. BUP して引きちぎられた SBが M 2 に抢いて徐々に薄く溶融し始めるが，M 1 に達しても なお完全には溶融が完了せず，スクリユ溝内では押し側つ ライト寄りに位置する。溶融が進むにつれて SB はさらに 細かく分断されるが，再配置は行われず，スクリュ溝内に 広がった溶融樹脂の中に，不均一に分断されたソリッド片 が内包されたままの形態で, 下流側へと流動する. 飢餓率 12\%では, $6 \%$ とほぼ同傾向であるが, 各部で溶融がいっ そう遅延する様子が確認できた。このようにスクリュ高回 転速度での飢餓供給は, 大幅な溶融遅延現象と顕著な BUP
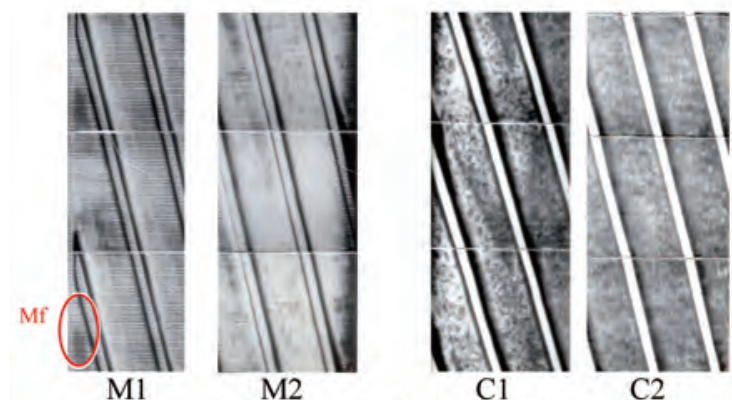

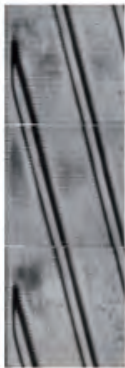

M1

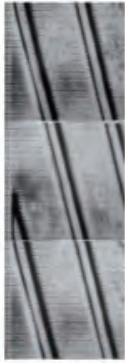

M1
$\mathrm{Cl}$

(1) Starvation ratio $0 \%$

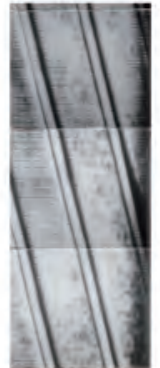

M2

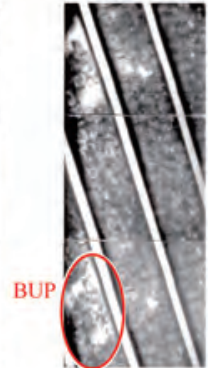

C1
C2

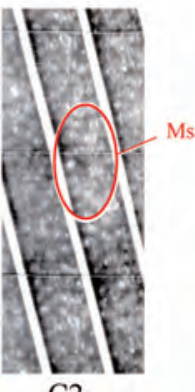

$\mathrm{C} 2$

(2) Starvation ratio $6 \%$

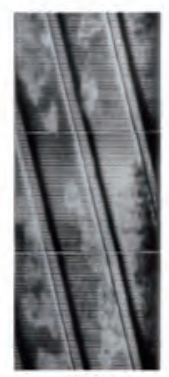

M2

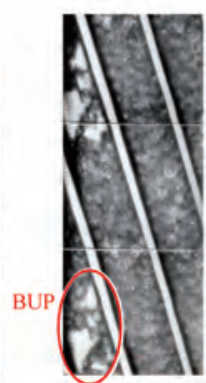

C1

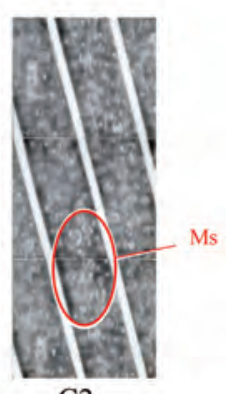

$\mathrm{C} 2$
(3) Starvation ratio $12 \%$

Fig. 10 Extended image of screw channel $(150 \mathrm{rpm} /$ Starvation ratio $0 \%, 6 \%, 12 \%)$

の生成をともなうことが確認された。このため，それによ る可塑化樹脂の不均一な溶融状況をもたらすことが示唆さ れた。

\section{5.飢餓供給における可塑化過程のモデル化}

\section{1 スクリュ回転速度と飢餓率による可塑化過程の遷移}

可視化観察実験結果から得られた飢餓供給時の可塑化プ ロセスの遷移過程を, 満杯供給時と比較しながら図 11 に 整理して示す。まず，同図(1)にスクリ工低回転速度（30 $\mathrm{rpm}$ ）時の可塑化プロセスを示す。満杯供給時に比較して 飢餓供給時にはペレットがスクリュ溝内に完全充満する地 点（図中 $\mathrm{Fu} ）$ が大きく下流側（図中左側）にシフトする。 この Fuは飢餓率の増加にともない，さらに下流側にシフ トする. Fu と同様に, Ms も飢挠供給時には下流側にシ フトし, 飢餓率の増加にともなってさらに下流側へとシフ 卜する。これに対し, 溶融完了点（図中 Mf）は満杯供給, 飢餓供給を問わずほぼ同じ地点（計量部中間）に位置する。 SB の BUP はいずれの条件でも発生しない.

次にスクリュ高回転速度（150 rpm）時の可塑化プロセ スの遷移過程を同図 (2)に示す. 全体の傾向は，前述の低 回転速度時と同様であるが，満杯供給時のペレット完全充 


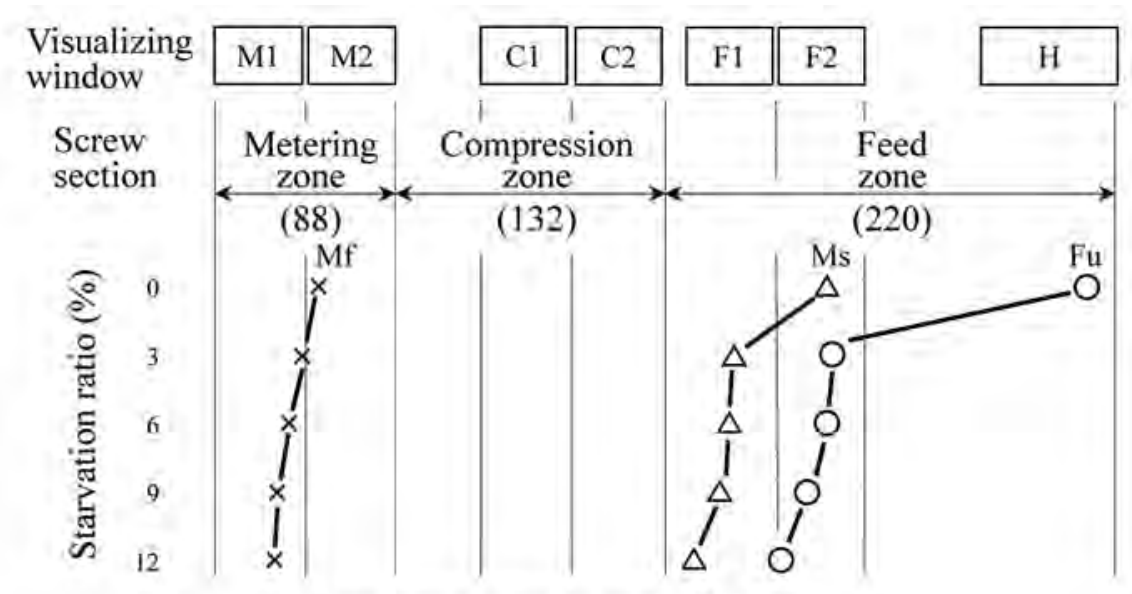

(1) Low screw rotation rate (30 rpm)

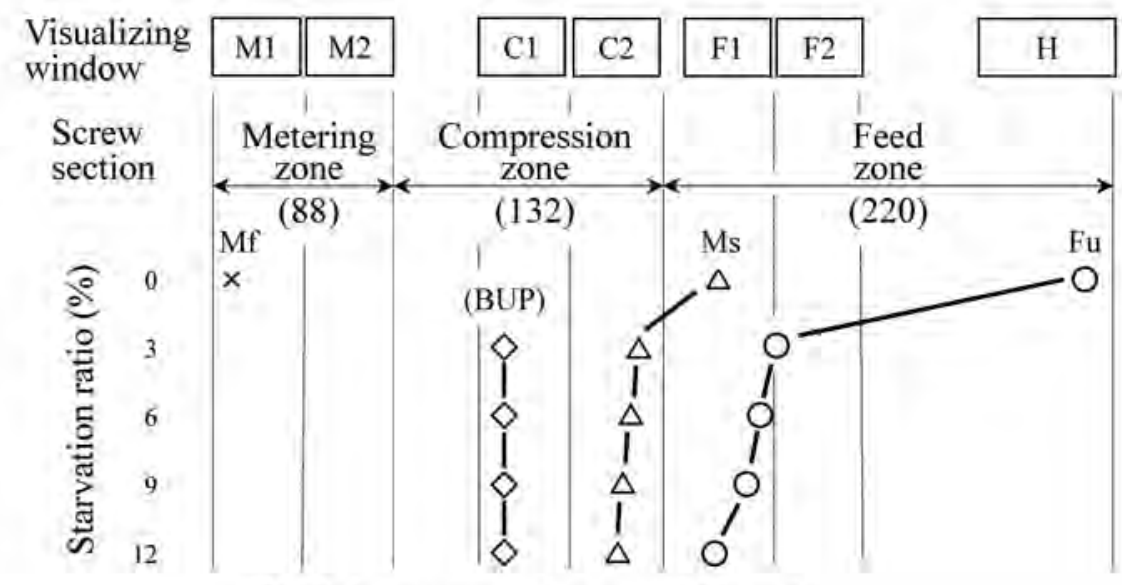

(2) High screw rotation rate (150rpm)

Fu: The point where pellets fill up screw channel Ms: The point where pellets start melting

Mf: The point where pellets finish melting

BUP: Break-up generation point

Fig. 11 Plastication model on the starve feeding process

填位置 Fu 以外，全ての可塑化プロセスは低スクリュ回転 速度時に比べてさらに下流側へとシフトする．溶融完了点 Mf はスクリユ計量部の最下流端までシフトし，特に飢餓 供給時には計量部内では溶融が完了せず，さらに下流域へ と Mf は持ち越される。これとほぼ呼応するように圧縮部 下流域から計量部にかけて, SB の BUP が発生する.

\section{2 供給部前半におけるペレット挙動モデル}

可視化観察実験結果から，飢餓供給時のスクリュ供給部 では，樹脂ペレットが満杯供給時のようにペレット塊を形 成し剛体のように輸送されるわけではなく, 空隙を伴って 輸送される挙動を示すことが明らかになった．満杯供給時 に, ペレット塊とスクリュ表面との摩擦力がシリンダ内壁 面との摩擦力より大きくなると, 樹脂ペレットの噛込み不 良 2) が発生し, 最悪の場合にはペレットが輸送されなく なる現象を誘発することが経験的に知られている．ところ が，飢餓供給時には，可視化観察結果に示されたように， 樹脂ペレットは圧縮部近傍まで凝集せず，スクリュ表面の 摩擦力は低いままに回転・並進運動するため, 満杯供給時 に見られるペレット塊とスクリュ・シリンダ壁面との摩擦
力のバランス欠如に起因する噛込み不良現象を回避するこ とが可能となることが示唆された.

\section{3 スクリュ低回転速度時の溶融モデル}

可視化観察実験結果より, 満杯供給時に比べて飢餓供給 時の Ms は遅延するものの，Mf はほぼ同じ位置となって いることが明らかになった。既報 ${ }^{1,2)} よ り ，$ 満杯供給時の 供給部では，剛体のように移動するペレット塊が，シリン ダ内壁面上に押し付けられ螺旋状の軌跡を描きながら接 触・移動することが明らかになっている. 本実験結果から, 飢餓供給時の供給部ではネジ送りのようにシリンダ底面を 滑るように直線的に輸送される様子が観察されたため, 満 杯供給時に比べて相対的にシリンダ内壁面からペレットへ の伝熱量の低下因子となっていることが示唆される。一方 で, 満杯供給時ではペレット塊の外表面（接触領域）のみ が局所的に加熱されるが, 可視化観察で示されたとおり飢 餓供給時には各ペレットが転がりながら移動するため, 輻 射伝熱効果と併せてペレット表面を効率よく均一に加熱で きることが推察される．このため，供給部を通過する時間 が比較的長いスクリュ低回転速度におけるペレット凝集時 
には，SB 内の各ペレット界面は相対的に高温であり，ス クリ工軸方向への移動では短い距離で溶融が完了するもの と考えられた。

\section{4 スクリュ高回転速度時の溶融モデル}

前述のスクリュ低回転速度時には, 効率的な溶融が行わ れるものの, スクリュ高回転速度時には, ペレット凝集後 の SB の軟化・溶融が大幅に遅延し, 満杯供給時と同様に BUP の発生が観察された. 圧縮部を経て計量部に至って も未溶融のペレット（BUP片）が多く存在することとな り，飢餓率が高いほど溶融不良を伴いやすいことが明らか になった。これらは, ペレット凝集前までのペレット表面 への伝熱量が少ないことに起因すると推察される.

BUP 生成のメカニズムは以下のように考察される。飢 餓供給時に圧縮部に到達したペレットは，上述したペレッ ト表面への伝熱効果に加えて, ペレット充満密度が低く, ペレット間の隙間が大きい状態で分布している。これによ り, 圧縮部でのペレット凝集時の SB 凝集力は低下する. 圧縮部でスクリュ溝深さが減少するにともなって, SB は シリンダとスクリュ表面に挟まれ，高速回転時にはシリン ダとの接触部には急激な局所的溶融が開始される。この溶 融樹脂は, 通常の満杯供給時の可塑化過程ではメルトフィ ルムを形成しつつ押し側フライトに掻き取られて MPを 形成するが，飢餓供給時にはフライトに掻き取られる前に， $\mathrm{SB}$ のペレット間に形成された緩い隙間に選択的に強制侵 入する.この SB の凝集力は低いため, 溶融樹脂はこうし た隙間（図 10(2), 同図 (3)のC 1 に観察される SB 内の白 い領域）を拡大するように流入し続け, 結果として SBに BUP を生成させた。この間, MP を形成するには至らな い. そのため, 高回転速度時には, 圧縮部を経て計量部に 至っても未溶融のペレット（BUP片）が多く存在するこ ととなり, 飢餓率が高いほど溶融不良を伴いやすいと推察 される。

\section{6. 結言}

本研究では, PPH 3（ホットカットPP）を用いて可塑 化実験を行い, 飢餓供給が可塑化過程に与える影響を調査 し，以下の結論を得た。

(1) 可視化観察結果より, 飢餓供給時には満杯供給時に対 して, ペレットがスクリュ溝内を充満する地点, および 溶融開始する地点が下流側に移動すること, これらは飢 餓率, スクリ工回転速度の増加にともない, より下流側 に移動することが確認された．溶融が完了する地点は, 低回転時には満杯供給とほぼ同じとなること, 高回転時
には計量部でも溶融が完了せず，圧縮部から計量部にか けて SB の BUP が発生することが確認された.

（2）飢餓供給時には，樹脂ペレットは空隙をともなって圧 縮部近傍まで輸送されることが確認された。このため, 満杯供給時に見られる，ペレット凝集体およびシリンダ とスクリュとの摩擦力の不均衡に起因する噛込み不良現 象の回避が可能となることが示唆された.

（3）樹脂圧力は，ノズル部，計量部，圧縮部いずれも，同 一スクリュ回転速度では満杯供給時よりも低く示された。 同一飢餓率では，ノズル部と計量部では回転速度の増加 にともない圧力の増加傾向が, 圧縮部では減少傾向が示 されることが確認されたが, 飢餓供給の高回転時は, BUP 生成の影響によって, 計量・圧縮部の圧力と回転速 度の相関，また飢餓率との相関がいずれも低く示された。 （4）同一スクリュ回転速度でのノズル部, 計量部の樹脂温 度は，飢餓率によらずほぼ一定であること，同一飢餓率 ではノズル部の樹脂温度は回転速度とともに上昇するが, 計量部では回転速度によらずほぼ一定となることが示さ れた。

（5）飢餓供給時の可塑化プロセスとして以下を提案した. 樹脂ペレットは充満密度が低いまま供給部上流域を輸送 され, 個々に受熱し転がりながら供給部下流域で凝集す る. 圧縮部で表面が加熱されたペレットが凝集一体化す る際に, 高温のペレット界面を挟持・内包するため, 短 時間に溶融が完了する。この際, 明確な MP の生成を ともなわない，スクリ工低回転速度では効率的な溶融が 行われるが，回転速度の増加によりプロセスは遅延して 下流側にシフトし, 溶融不良と SBのBUP 発現を招く 可能性が高まる.

\section{参 考 文 献}

1 ）横井秀俊, 高次 聡, 白石 亘：生産研究, 52, 410 (2000)

2 ）横井秀俊, 高次 聡：成形加工, 12(7), 457 (2000)

3 ) 白岩信裕：Journal of the Japan Society of Colour Material, 78(5), 233(2005)

4 ) 浅野 強：日本接着学会誌，39(11)，426(2003)

5 ) Strand, S. R., Spalding, M. A. and Hyun, K. S. : Plastics Engineering, 48(7), 17 (1992)

6 ）横井秀俊, 龍野道宏 : 成形加工, $13(8), 571(2001)$

7 ）横井秀俊, 龍野道宏：成形加工，14(10)，678(2002)

8 ）横井秀俊, 岩崎龍一, 平野彰士, 鈴木謙克, 坂井秀敏 : 成形加工'91，15(1991) 